\title{
GASTRIC PROTEOLYSIS IN DISEASE \\ 3. THE PROTEOLYTIC ACTIVITY OF GASTRIC JUICE IN CHRONIC HYPOCHROMIC ANAEMIA AND IN IDIOPATHIC STEATORRHOEA
}

\author{
BY \\ W. H. TAYLOR* \\ From the Department of Clinical Biochemistry, Radcliffe Infirmary, University of Oxford
}

In chronic hypochromic anaemia the mean pepsin concentration of the gastric juice is reduced and in some patients the enzyme is totally absent (Davies, 1931 ; Castle, Heath, and Strauss, 1931 ; Meulengracht, 1932 ; Hartfall and Witts, 1933 ; Griffiths, 1934 ; Mullins and Flood, 1935 ; Aitken, Spray, and Walters, 1954). Aitken et al. (1954) divide their patients into those with and without achlorhydria. Complete absence of pepsin was found only among the former and the mean pepsin concentration in this group was less than a quarter of that in the patients who secreted free acid.

In idiopathic steatorrhoea the pepsin concentration of the gastric juice has been determined by Polland and Bloomfield (1930) in one case, Castle et al. (1931) in one case, and Aitken et al. (1954) in 10 cases. In six of these cases the gastric juice had a normal pepsin concentration, in four a subnormal concentration, and in two it was pepsin-free.

Slight proteolytic activity of gastric juice has also been detected at neutral $p \mathrm{H}$ in chronic hypochromic anaemia (Griffiths, 1934; Lasch, 1937 ; Jones and Wilkinson, 1938), and in idiopathic steatorrhoea in remission but not in relapse (Fox, 1949).

In both diseases, therefore, a reduced secretion of pepsin confirms the evidence for gastric dysfunction which is derived from gastric mucosal biopsy and from the reduced secretion of gastric hydrochloric acid. There is, however, an underlying assumption that diminished proteolytic activity results from a simple quantitative deficiency of normal pepsin. Estimations of gastric proteolytic activity have been carried out only near $p \mathrm{H} 2$ and 7 . The possibility that the gastric secretion in these diseases may contain enzymes different from normal, or differing proportions of normal enzymes, as is the case

\footnotetext{
*Present address: Department of Chemical Pathology, United Liverpool Hospitals, Ashton Street, Liverpool, 3.
}

in pernicious anaemia (Taylor, 1959d), does not seem to have been considered. An investigation of this possibility is now described.

\section{Materials and Methods}

The methods and materials used have been described previously (Taylor, 1956, 1957, 1959a).

\section{Results}

Chronic Hypochromic Anaemia.-Curves of $p \mathrm{H}$ activity for digestion of plasma protein by gastric juice have been determined in 10 patients (Table $I$ and Fig. 1). Of these, one secreted juice withoutactivity below $p \mathrm{H}$ 5. Two gave essentially normal curves with two maxima occurring in the $p \mathrm{H}$ ranges 1.8 to 2.4 and 3.5 to 3.7 . One patient

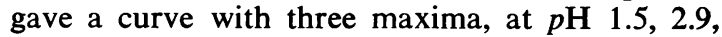
and 3.9, which resembled curves shown by a minority of normal subjects (Taylor, 1959a). Of

TABLE I

$p H$ MAXIMA FOR DIGESTION OF PROTEINS BELOW $p H 5$ BY GASTRIC JUICE OF PATIENTS WITH CHRONIC HYPOCHROMIC ANAEMIA

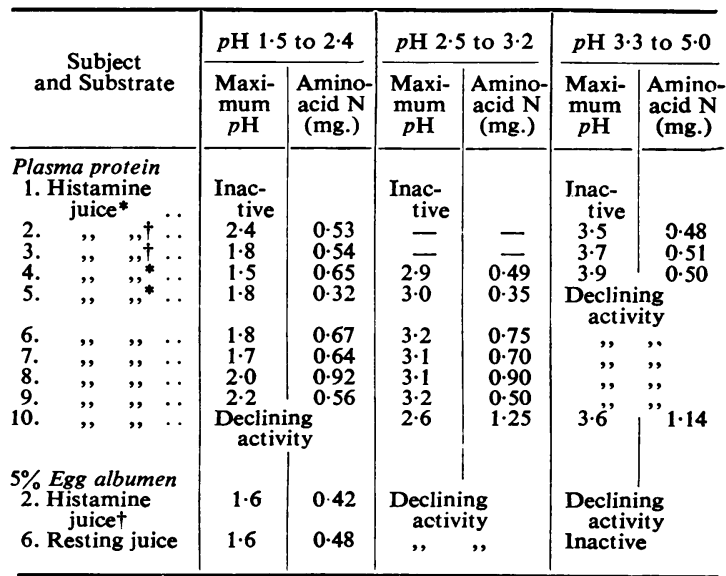

In the tables and figures the amount of liberated amino-acid $\mathrm{N}$ is that of the whole digest, which consisted of $5 \mathrm{ml}$. buffer, 1 or $2 \mathrm{ml}$. of gastric juice, and $1 \mathrm{ml}$. of plasma or $5 \% \mathrm{egg}$ albumen.

* Patients with achlorhydria.

+ Patients with chronic blood loss. 


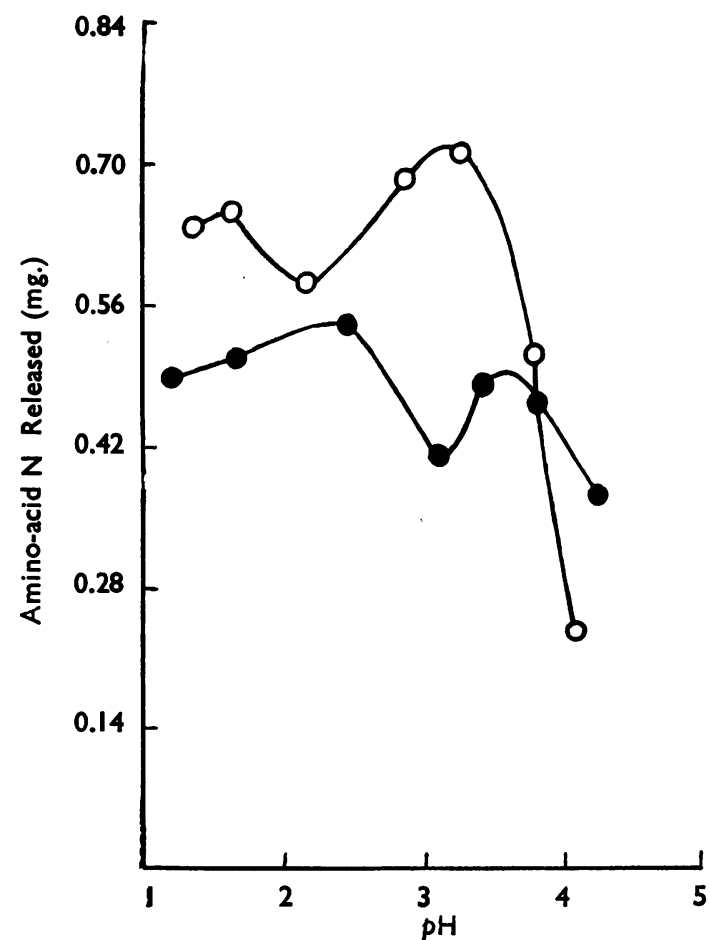

Fig. 1.-Curves of $p \mathrm{H}$ activity for the digestion of plasma protein by the gastric juice of two patients with chronic hypochromic anaemia. One $(\theta)$ had suffered chronic blood loss and one $(O)$ from idiopathic hypochromic anaemia. $37^{\circ} \mathrm{C} ., 3 \mathrm{hr}$.

TABLE II

pH MAXIMA FOR DIGESTION OF PROTEINS AT $p H 5$ to 8.5 BY GASTRIC JUICE FROM PATIENTS WITH CHRONIC HYPOCHROMIC ANAEMIA AND IDIOPATHIC STEATOR-

\begin{tabular}{|c|c|c|c|}
\hline Subject & Substrate & $\underset{\substack{p \mathrm{H} \\
\text { Maximum }}}{2}$ & $\underset{\text { (mg.) }}{\text { Amino-acid } N}$ \\
\hline $\begin{array}{c}\text { Chronic hypo- } \\
\text { chromic anaemia } \\
1 \\
2 \\
3 \\
5 \\
6 \\
7 \\
9 \\
\text { Idiopathic } \\
\text { steatorrhoea } \\
1 \\
2 \\
6 \\
5\end{array}$ & $\begin{array}{l}\text { Plasma } \\
\text { 5\% serum } \\
\text { albumin }\end{array}$ & $\begin{array}{c}7.6 \\
6.9 \\
\text { In } \\
\text { Active, } \\
\quad " \text { In } \\
\\
\\
6.8 \\
7.2 \\
7.2 \\
\text { Active, }\end{array}$ & $\begin{array}{l}\quad \begin{array}{l}0.12 \\
0.14\end{array} \\
\text { tive } \\
\text { maximum } \\
\text { tive " }\end{array}$ \\
\hline
\end{tabular}

the remaining six patients, five gave curves with two maxima, which fell within the $p \mathrm{H}$ ranges 1.5 to 2.2 and 2.9 to 3.2. These ranges are those associated with the proteolytic activity of pyloric mucosal extracts in normal subjects (Taylor, 1959b). The remaining patient gave a $\mathrm{pH}$ activity curve with double maxima at $p \mathbf{H} 2.6$ and 3.6. Such a finding has not been made in normal subjects.

Curves of $p \mathrm{H}$ activity for the digestion of egg albumen by gastric juice were determined in two subjects. Both showed only a single maximum at $p H$ 1.6. One of these subjects had shown with plasma a normal digestion curve with two maxima and the other a curve of the "pyloric" type. These curves are similar to those found when normal gastric juice digests egg albumen.

Observations on the proteolytic activity of gastric juice upon plasma protein at $p \mathrm{H} 5$ to 8.5 were made in seven patients of whom three exhibited no activity (Table II). Two showed slight activity at $p \mathrm{H} 7.4$ to 7.7 , but no maximum could be ascertained. Two gave curves with single maxima, one at $p H 6.9$ and the other at $p H$ 7.6. These results do not differ from those obtained in normal subjects (Taylor, 1956, 1959c).

Idiopathic Steatorrhoea.-The gastric juice of four patients digested plasma protein below $p \mathrm{H} 5$ with maxima in the $p \mathrm{H}$ ranges 1.5 to 1.9 and 2.8 to 3.0 (Table III, Fig. 2). These maxima are similar to those shown by human pyloric mucosal extracts. The gastric juice of one of these patients

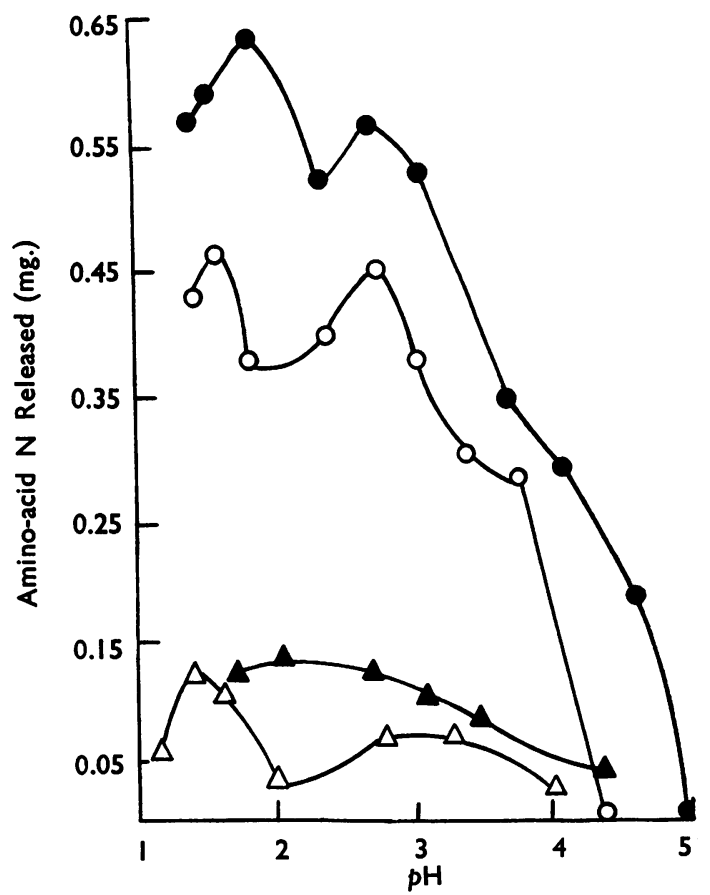

FiG. 2.-Curves of $p \mathrm{H}$ activity for the digestion of protein substrates by the gastric juice of four patients wih idiopathic steatorrhoea. Plasma protein $(\bullet \circ \Delta)$, serum albumin $(\Delta), 37^{\circ} \mathrm{C} ., 3 \mathrm{hr}$. 
TABLE III

pH MAXIMA FOR DIGESTION OF PROTEINS BELOW $p H 5$ BY GASTRIC JUICE OF PATIENTS WITH IDIOPATHIC STEATORRHOEA

\begin{tabular}{|c|c|c|c|c|c|c|}
\hline \multirow{2}{*}{$\begin{array}{c}\text { Subject } \\
\text { and Substrate }\end{array}$} & \multicolumn{2}{|c|}{ pH 1.5 to 2.4} & \multicolumn{2}{|c|}{$p H 2.5$ to 3.2} & \multicolumn{2}{|c|}{ pH 3.3 to 4.0} \\
\hline & $\underset{p H}{\operatorname{Maxi}}$ & $\begin{array}{c}\text { Amino- } \\
\operatorname{acid} \mathbf{N} \\
\text { (mg.) }\end{array}$ & $\underset{p H}{\operatorname{maxi-}}$ & $\begin{array}{c}\text { Amino- } \\
\text { acid N } \\
\text { (mg.) }\end{array}$ & $\underset{p H}{\operatorname{maxi}-}$ & $\begin{array}{c}\text { Amino } \\
\operatorname{acid} \mathbf{N} \\
(\mathbf{m g} .)\end{array}$ \\
\hline $\begin{array}{l}\text { Plasma protein } \\
\text { 1. Histamine juice }\end{array}$ & 1.9 & 0.62 & $2 \cdot 8$ & 0.56 & $\begin{array}{l}\text { Declini } \\
\text { activ }\end{array}$ & $\begin{array}{l}\text { ing } \\
\text { ity }\end{array}$ \\
\hline $\begin{array}{lll}\text { 2. } & , & , \\
\text { 3. } & , " & , " *\end{array}$ & $\begin{array}{l}1.9 \\
1 \cdot 5 \\
1 \cdot 5\end{array}$ & $\begin{array}{l}0.64 \\
0 \cdot 12 \\
0.46\end{array}$ & $\begin{array}{l}3 \cdot 0 \\
3 \cdot 0 \\
2 \cdot 8\end{array}$ & $\begin{array}{l}0.59 \\
0.07 \\
0.45\end{array}$ & $\begin{array}{l}\text {," } \\
\text {," }\end{array}$ & ,", \\
\hline $\begin{array}{l}5 \% \text { Human serum } \\
\text { albumin } \\
\text { 5. Histamine } \\
\text { juice* }\end{array}$ & $2 \cdot 2$ & $0 \cdot 13$ & $\begin{array}{l}\text { Declini } \\
\text { activ }\end{array}$ & $\begin{array}{l}\text { ing } \\
\text { ity }\end{array}$ & "’ & ", \\
\hline $\begin{array}{l}\text { 2\% Casein } \\
\text { 4. Histamine } \\
\text { juice* }\end{array}$ & $1 \cdot 8$ & $0 \cdot 14$ & $2 \cdot 6$ & $0 \cdot 12$ & ", & "' \\
\hline $\begin{array}{l}5 \% \text { Egg albumen } \\
\text { 4. Histamine } \\
\text { juice* }\end{array}$ & 1.6 & 0.14 & $\begin{array}{r}\text { Declini } \\
\text { activ }\end{array}$ & & ", & , \\
\hline
\end{tabular}

* Patients with achlorhydria.

was also incubated with casein, giving a $p \mathrm{H}$ activity curve with maxima at 1.8 and 2.6 , and with egg albumen, giving a single maximum at $p H$ 1.6. In a fifth patient human serum albumin was used as substrate and only a single maximum at $p \mathrm{H} 2.2$ was observed.

The juices, which were not bile stained, of three patients also digested plasma protein weakly at $p \mathrm{H} 6$ to 8 with maxima at $p \mathrm{H} 6.8$ to 7.2. In a fourth patient a very slight hydrolysis of human serum albumin at $p \mathrm{H} 7.1$ could be demonstrated. These results are similar to those observed in normal subjects (Taylor, 1959c).

\section{Discussion}

Only the two patients whose anaemia resulted from chronic blood loss exhibited normal gastric

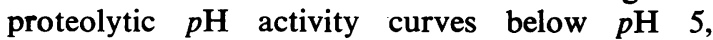
although one patient gave a curve with three maxima, which may perhaps also be considered normal. The principal difference from normal in the other patients was the occurrence of pylorictype curves. A group of similar pyloric-type curves was found in patients with pernicious anaemia (Taylor, 1959d), a disease in which it is known that the mucosa of the body and fundus is atrophied whereas that of the pylorus may be preserved. Gross atrophy of the fundus and body of the stomach, as severe as that seen in pernicious anaemia, has also been observed in hypochromic anaemia but is relatively rare, occurring only in about $10 \%$ of patients (Lees and
Rosenthal, 1958). Severe gastric mucosal atrophy might therefore perhaps account for the inactive juice of one patient but is unlikely to account for the pyloric pattern that has been observed in as many as five of 10 patients, especially as four of them could still secrete gastric acid.

A more likely explanation of the prevalence of the pyloric pattern in hypochromic anaemia is an alteration in the proportions of "pyloric" and "fundic" pepsins (Taylor, 1959b) secreted by the non-pyloric parts of the stomach. There is evidence that the neck chief cells of the fundic glands, which histologically resemble the cells of the pyloric glands, normally secrete a different pepsin from the " true" chief cells (LinderstrømLang, Holter, and Ohlsen, 1935 ; LinderstrømLang, 1952) and there is circumstantial evidence (Taylor, 1959b) that this enzyme of the neck chief cells resembles pyloric pepsin in activity. In normal gastric juice, however, fundic pepsin from the "true" chief cells preponderates. In hypochromic anaemia there is a tendency for the neck chief cells to proliferate at the expense of the "true" chief cells. Lees and Rosenthal (1958) found that in four of 19 patients there was " marked replacement of normal by pseudopyloric glands." Such a replacement of "true" chief cells by cells of the pyloric type might result in "pyloric" pepsin becoming the predominant enzyme, and it would thus be possible to explain the pyloric type of $p \mathrm{H}$ activity curve which has been observed.

In idiopathic steatorrhoea gastric mucosal atrophy varies from slight to very severe, and it is possible that a similar explanation to that advanced in hypochromic anaemia may account for the predominance of pyloric-type proteolytic $p \mathrm{H}$ activity curves.

Only in one patient with hypochromic anaemia (No. 10) and one with idiopathic steatorrhoea (No. 5) is it impossible to explain the proteolytic $p \mathrm{H}$ activity curves in terms of normally occurring gastric enzymes. In both these patients, and especially in No. 10, whose gastric juice was very active, the deviation from normal is unlikely to be erroneous, and the possibility that abnormal pepsins may have been elaborated arises. In general, however, it is evident that in hypochromic anaemia and idiopathic steatorrhoea the abnormal gastric proteolytic $p \mathrm{H}$ activity curves are adequately explained by postulating the secretion of abnormal proportions of normal enzymes so that these diseases stand in contrast to pernicious anaemia, in which some abnormal curves can only be explained by postulating the synthesis of abnormal and pathological pepsins. 


\section{Summary}

The proteolytic activity of the gastric juice from 10 patients with chronic hypochromic anaemia and five patients with idiopathic steatorrhoea has been investigated at $p \mathrm{H} 1.5$ to 8 .

The pattern of activity at $p \mathrm{H} 5$ to $8.5 \mathrm{did}$ not differ from that of normal subjects.

Below $p \mathrm{H} 5$ only three patients with hypochromic anaemia exhibited normal $p H$ activity curves. One secreted inactive gastric juice. Five patients with hypochromic anaemia and four with idiopathic steatorrhoea exhibited $p H$ activity curves resembling those of normal pyloric mucosal extracts.

It is suggested that in both diseases these pyloric-type curves result from the secretion of pyloric-type pepsin from the gastric mucosa in relatively increased amounts.

I wish to thank Miss Barbara Hunt and Mr. Brian Collett for skilful assistance with part of this work, the patients who donated gastric juice, many members of the Nuffield Department of Clinical Medicine for collecting gastric juice, and Mr. J. R. P. O'Brien and Dr. R. B. Fisher for reading the D.M. thesis from which this paper is abridged.

\section{REFERENCES}

Aitken, M. A., Spray, G. H., and Walters, G. (1954). Clin. Sci., 13, 119.

Castle, W. B., Heath, C. W., and Strauss, M. B. (1931). Amer. J. med. Sci., 182, 741 .

Davies, D. T. (1931). Quart. J. Med., 24, 447.

Fox, H. J. (1949). J. clin. Invest., 28, 687.

Griffiths, W. J. (1934). Biochem. J., 28, 671.

Hartfall, S. J., and Witts, L. J. (1933). Guy's Hosp. Rep., 83, 24.

Jones, T. S. G., and Wilkinson, J. F. (1938). Biochem. J., 32, 1352

Lasch, F. (1937). Klin. Wschr., 16, 810.

Lees, F., and Rosenthal, F. D. (1958). Quart. J. Med. (n.s.), 27, 19.

Linderstrom-Lang K. U. (1952), Lane Medical Lectures: Proteins and Enzymes (Stanf. Univ. Publ. Med. Sci., Vol. Vn).

- Holter, H., and Ohlsen, A. S. (1935). C.R. Lab. Carlsberg, 20, No. $11,66$.

Meulengracht, E. (1932). Acta med. scand., 78, 387.

Mullins, C. R., and Flood, C. A. (1935). J. clin. Invest., 14, 793.

Polland, W. S., and Bloomfield, A. L. (1930). Ibid., 9, 107.

Taylor, W. H. (1956). D.M. thesis, University of Oxford.

- (1957). Analyst, 82, 488.

- (1959a). Biochem. J., 71, 73.

- (1959b). Ibid., 71, 384.

- (1959c). Ibid., 71, 626.

_ (1959d). J. clin. Path., 12, 210. 